\title{
Dual-function hydrotalcite-derived adsorbents with sulfur storage properties: Dyes and hydrotalcite fate in adsorption-regeneration cycles
}

\author{
Wojciech Stawiński a, Agnieszka Węgrzyn b, *, Olga Freitas a, Lucjan Chmielarz b, \\ Sónia Figueiredo a \\ a REQUIMTE, LAQV, Instituto Superior de Engenharia do Porto, Instituto Politéecnico do Porto, Rua Dr. Antó nio \\ Bernardino de Almeida 431, 4200-072, Porto, \\ Portugal \\ b Faculty of Chemistry, Jagiellonian University, ul. Ingardena 3, 30-060, Krakó w, Poland
}

\begin{abstract}
Thermal treatment of hydrotalcite at increasing temperatures resulted in formation of mixed oxides that exhibited different adsorption behavior toward anionic and cationic industrial dyes. The material annealed at $450{ }^{\circ} \mathrm{C}$ was characterized by the highest maximum adsorption capacity for both types of dyes. The adsorption was strongly $\mathrm{pH}$ dependent and for the anionic dye abatement low $\mathrm{pH}$ was favored

whilst higher $\mathrm{pH}$ was more preferable for removal of the cationic dye. According to the equilibrium experiments, the maximum adsorption capacity increased from $179 \pm 5$ to $291 \pm 8 \mathrm{mg} \mathrm{g}^{-1}$ in case of the anionic dye at $\mathrm{pH} 3.5$ and from $6 \pm 2$ to $48 \pm 2 \mathrm{mg} \mathrm{g}^{-1}$ in case of the cationic dye at $\mathrm{pH} 8.0$, on starting and

thermally treated material at $450{ }^{\circ} \mathrm{C}$, respectively. Detailed characteristics of spent adsorbent and its reconstructed form revealed that after each cycle of adsorption and thermal regeneration the maximum adsorption capacity of the material decreased due to changes in the structure and accumulation of sulfur compounds. Evolution of specific surface area and porosity was correlated with annealing temperatures and behavior of dye's residues.
\end{abstract}

Keywords: Hydrotalcite; Thermal treatment; Removal of dyes; Spent adsorbent; Sulfur accumulation 


\section{Introduction}

Colored wastewater is created as a result of the production of the dye and as well as a direct consequence of its use in the textile and related industries. Consumption of colored textiles, which is one of the basic technologies in human civilization, is steadily increasing worldwide, following the growth of world population [1]. The textile dyeing and finishing industry, being one of the most chemically intensive industries on earth has created major envi- ronmental problems and is the second greatest polluter of clean water, right after agriculture. Many of chemicals present in wastewaters are cause of significant environmental degradation and human diseases [2]. Dyes can exhibit acute toxicity, sensitiza- tion, chronic effects after repeated application, mutagenic and carcinogenic effects on human. Dyestuffs, being intensely colored, are usually the first contaminant to be recognized in wastewaters and present special problems because even a small amount is highly visible. They can exhibit ecotoxicity and affect transparency and gas solubility of water bodies. By absorbing the sunlight entering water they alter growth of the aquatic species and hinder photosynthesis upsetting natural ecosystems. Synthetic dyes are in general not readily biodegradable and chemically stable thus traditional wastewater treatment techniques are ineffective. It is also important to handle the residues and byproducts obtained after decolorization process because many of them have negative influence on environment [3] The development of efficient, economic and environmentally friendly technologies to remove color and detoxify the wastewaters to acceptable levels and decrease their environmental impact at affordable cost is the first and major concern of the utmost importance [4,5]. Among many other tech- niques adsorption is considered as one of the best wastewater treatment methods due to its universal nature, ease of operation, ability to remove soluble and insoluble organic pollutants, high removal capacity and possibility to recycle and reuse many of ad- sorbents [6,7]. Activated carbon is the most widely used adsorbent however, its preparation is generally energy-consuming and commercially available product are relatively expensive, which may hamper its application [4,8]. This has triggered a growing interest in production of low-cost adsorbents.

Hydrotalcite-like (HTL) materials, layered double hydroxides (LDH) or anionic clays are the common names given to a wide family of layered materials with both divalent and trivalent metallic cations in the main, positively charged layers and an interlayer anionic species balancing the layers charge. The interlayer anion can be almost freely exchanged for a wide possible selection of anionic compounds present in liquid phase. The principal areas of interest, among others, include their application as adsorbents. A unique property of such materials is that after thermal treatment under mild conditions, they are able to reconstruct the layered structure which opens a possibility for regeneration of a spent adsorbent $[9,10]$.

Hydrotalcite-like materials (HT) have been already tested as adsorbents of various pollutants. Regarding removal of dyes by MgAl-hydrotalcite and derived mixed oxides $\mathrm{Li}$ et al. [11] investi- gated adsorption of Congo Red onto raw and $\mathrm{HT}$ calcined at $700{ }^{\circ} \mathrm{C}$.

Heraldy et al. [12] focused of removal of Eosin Yellow, Methyl Or- ange and Methylene Blue by commercial and synthesized hydro- talcite. Shan et al. [13]; Zhang et al. [14]; Mustapha Bouhent et al.

[15] tested adsorption properties of HT towards removal of Reactive Red, Congo Red, Acid Red 1, and Brilliant Red, and Orange II, respectively. Santos et al. [16] removed Acid Green 68:1 with un- calcined and $\mathrm{HT}$ annealed at $550{ }^{\circ} \mathrm{C}$, Extremera et al. [17] used temperature of $500^{\circ} \mathrm{C}$ to calcine $\mathrm{HT}$ in order to remove Acid Orange

10. The influence of $\mathrm{pH}$ and temperature on the on adsorption of Ramazol Yellow GR110 and Ramazol Gonden Yellow RNL onto calcined at $500^{\circ} \mathrm{C}$ hydrotalcite was investigated by Teixeira et al. [18]. Flores et al. [19] prepared their adsorbent at $450{ }^{\circ} \mathrm{C}$ to adsorb Astrazon Remazol, Briliant Blue and Direct Red. Temperature of $600{ }^{\circ} \mathrm{C}$ was used by El Gaini et al. [20] to obtain material to remove Indigo Carmine, 500

${ }^{\circ} \mathrm{C}$ was applied by Drici Setti et al. [21]; Auxilio et al. [22]; Bascialla and Regazzoni [23]; and Zhu et al. [24] to remove Benzopurpurine 4B, Acid Blue 9, Acid Blue 113, and Brilliant Blue R, respectively. Hydrotalcite, its calcined at $500{ }^{\circ} \mathrm{C}$ version, and calcined and intercalated with sodium dodecylsulfate material were applied for removal of Green Beznatyl-F2B by Bouraada et al. [25]. Orthman et al. [26] studied removal of colored substances (dyes and melanodin) form various aqueous solutions by hydro- talcite with varying $\mathrm{Mg}:$ Al ratio. 
With respect to adsorption of other pollutants by LDH, Das et al. [27] investigated adsorption of selenite on raw and calcined at $500{ }^{\circ} \mathrm{C} \mathrm{MgFeCO}_{3}$ layered double hydroxide. Barriga et al. [28] evaluated effects of layer charge, interlayer anion and nature of the trivalent cation in LDH on sorption of 2,4,6-trinitrophenol in raw and calcined at 500

${ }^{\circ} \mathrm{C}$ adsorbents. Terephthalate anions were adsorbed onto uncalcined and calcined at $500{ }^{\circ} \mathrm{C}_{\mathrm{MgAlCO}_{3}}$ hydro- talcite by Crepaldi et al. [29]. The same type of adsorbent was tested

by Lazaridis [30] paying special attention to phosphates, thiocya- nates, cadmium, lead and nickel ions.

However, only a few authors raise the issue of recycling and reuse of prepared adsorbents in adsorptiondesorption cycles, which is essential in order to reduce deleterious after-effects on the environment during cleanup processes, known as the "footprint" of remediation [31]. Das et al. [27] used a solution of $\mathrm{NaOH}$ to regenerate the developed material, Crepaldi et al. [29] turned to

thermal regeneration at $500{ }^{\circ} \mathrm{C}$ as well as Teixeira et al. [32] and

Drici Setti et al. [21]. Recycling by application of ion exchange using chloride, carbonate, and hydroxide anions was found ineffective by Teixeira et al. [18]. Extremera et al. [17] touched the problem of regeneration of spent adsorbent and recovery of adsorbed dye for further use. The dye was successfully desorbed in aqueous solution containing carbonates. However, an attempt to regenerate such treated adsorbent by calcination did not produce good results and the adsorption capacity was not regained. Thermal regeneration was also used by Orthman et al. [26] to successfully remove adsorbed organic compounds form their adsorbent. Furthermore, characterization of spend adsorbents is neglected and very rarely found in the literature. Understanding what changes the adsorbent is subjected to upon each cycle of adsorption and regeneration is crucial to the design of water treatment processes in order to avoid production of waste sludge which disposal is still a problem and generates additional costs [33,34].

The aim of this study was to present a broad insight on changes in the functionality as adsorbents of hydrotalcite derived mixed oxides depending on calcination temperature used in their treat-ment and $\mathrm{pH}$ of the wastewater, and to provide an ample study on fate of the spent adsorbent on each step of its recycling in several adsorption/desorption cycles.

\section{Experimental}

\subsection{Materials}

\subsubsection{Adsorbent preparation and characterization}

Hydrotalcite $(\mathrm{HT})$ with formula $\left[\mathrm{Mg}_{0.67} \mathrm{Al}_{0.33}(\mathrm{OH})_{2}\right]\left(\mathrm{CO}_{3}\right)_{0.165} \$ 2 \mathrm{H}_{2} \mathrm{O}$, was prepared by co-precipitation method. A solution of $0.667 \mathrm{M} \mathrm{MgCl}_{2}$ and $0.333 \mathrm{M} \mathrm{Al}\left(\mathrm{NO}_{3}\right)_{2} \$ 9 \mathrm{H}_{2} \mathrm{O}$ was added drop-wise from one dropping funnel and a solution of $2 \mathrm{M} \mathrm{NaOH}$ was added from

another dropping funnel to a $0.160 \mathrm{M}$ solution $\mathrm{Na}_{2} \mathrm{CO}_{3}$ while keeping it at $\mathrm{pH} 10$, temperature $60{ }^{\circ} \mathrm{C}$ under constant stirring. Prepared HT was washed four times in hot water $\left(70{ }^{\circ} \mathrm{C}\right)$, filtered, left to dry for $24 \mathrm{~h}$ at $100{ }^{\circ} \mathrm{C}$ and ground with a mortar.

Hydrotalcite-derived mixed oxides (HTox) were prepared by calcinating of $\mathrm{HT}$ in a muffle furnace at different temperatures 300, 450, 600 and $750{ }^{\circ} \mathrm{C}$ (originating HToxC300, HToxC450, HToxC600 and $\mathrm{HToxC} 750$ respectively) according to the following procedure: heating rate of $2{ }^{\circ} \mathrm{C} \mathrm{min}^{-1}$ followed by $6 \mathrm{~h}$ of calcination at given temperature.

The structure of the materials was studied with X-ray powder diffractometer (Bruker, D2 PHASER) equipped with CuKaradiation source. Infrared spectra of the samples were recorded using attenuated total reflectance technique (Nicolet 6700 FT-IR, Thermo Scientific). UVeVis-diffuse reflectance spectra were recorded using an Evolution 600 (Thermo) spectrophotometer. Samples were diluted before measurements with $\mathrm{Al}_{2} \mathrm{O}_{3}$ to lower the absorbance in order to obtain the measurable range (30 mg of the sample ground with $270 \mathrm{mg}$ of $\mathrm{Al}_{2} \mathrm{O}_{3}$ in a mortar). The textural parameters

of the samples were determined by adsorption of $\mathrm{N}_{2}$ at $196{ }^{\circ} \mathrm{C}$ using a 3Flex (Micromeritics) surface characterization analyzer on outgassed samples. The elemental 
organic analysis was performed using Vario Micro Cube elemental analyzer with electronic microbalance.

\subsection{Adsorbate}

Two dyestuffs, kindly supplied by DyStar, were used in the pH optimization, kinetics, equilibrium and adsorbent regeneration experiments: a cationic dye, Astrazon Red FBL 200\% (AR), CI 85496-37-3 and an anionic dye, Levafix Amber CA gran (AMB), which formula was not revealed by the manufacturer however, it is known to have a fluorotriazinedivinylsulphone structure.

Additionally, in order to better understand interactions of the dyes with adsorbent AMB and three other dyes, Reactive Red $184(\mathrm{R})$, Congo Red (CR) and Methyl Orange (MO), were used to saturate adsorbent calcined at $450{ }^{\circ} \mathrm{C}$ with excess of concentrated solutions

$\left(5 \mathrm{~g} \mathrm{~L}^{-1}\right)$. Suspensions were stirred for $24 \mathrm{~h}$, centrifuged (5 min at $4500 \mathrm{rpm}$ ), washed repeatedly with distilled water and left to dry at room temperature.

The structure of these dyes is presented in the Appendix (Fig. A1).

\section{Methods}

\subsection{Determination of dyestuff concentration}

The dyestuff concentration was measured using UVeVis spec- trometer (Thermo Scientific, Evolution 300) at the maximum absorbance wavelength of each dyestuff ( $230 \mathrm{~nm}$ for $A M B$ and $531 \mathrm{~nm}$ for AR).

\section{2. $\quad$ pH optimization in adsorption studies}

A portion of $20 \mathrm{mg}$ of each material was placed in Erlenmeyer flasks with $30 \mathrm{~mL}$ of $100 \mathrm{mg} \mathrm{L}^{-1}$ dye solution (AMB and AR). Each flask was adjusted to a different $\mathrm{pH}$ value, 3.5, 4.5, 5.0, 7.0, 8.0 and

9.0. Flasks were shaken for $2 \mathrm{~h}$ at room temperature, centrifuged (1 min at $4500 \mathrm{rpm}$, Sartorius, Sigma 2e16) and the dye concen- tration was determined.

\subsubsection{Kinetic experiments}

Kinetic experiments were conducted using a magnetic stirrer, at room temperature, and at $400 \mathrm{rpm}$. The experiment was conducted at $\mathrm{pH} 3.5$ for every sample and additionally at $\mathrm{pH} 8.0$ only for HToxC450. Masses of $100 \mathrm{mg}$ of each material were placed in round-bottom flasks and $200 \mathrm{~mL}$ of $200 \mathrm{mg} \mathrm{L}-1$ the dyes solution (AMB and AR). Samples were collected in selected time intervals, immediately centrifuged and then concentration of the dye was determined.

\subsubsection{Equilibrium experiments}

Adsorption isotherms were obtained at room temperature, at $\mathrm{pH}$ adjusted to 3.5 for all samples and additionally at $\mathrm{pH} 8.0$ only for HToxC450. Weighted portions of $20 \mathrm{mg}$ of each material were placed in Erlenmeyer flasks with caps and mixed with $30 \mathrm{~mL}$ of dyes solutions (AMB and AR) of varying concentrations $\left(10 \mathrm{mg} \mathrm{L}^{-1}\right.$ to $300 \mathrm{mg} \mathrm{L}^{-1}$ ). Flasks were shaken for $4 \mathrm{~h}$, then solutions were centrifuged and concentration of the dye determined in each flask.

\subsubsection{Regeneration of the spent adsorbent}

Weighted portions of each sample were saturated in concen- trated solution of $\mathrm{AMB}$ during $2 \mathrm{~h}$ in Erlenmeyer flasks with $\mathrm{pH}$ adjusted to 3.5 and another series was made without $\mathrm{pH}$ adjust- ment. In the latter case the final $\mathrm{pH}$ was equal to 6.0. Samples were centrifuged (5 min at $4500 \mathrm{rpm}$ ) and left to dry at $40{ }^{\circ} \mathrm{C}$ for $12 \mathrm{~h}$.

After that each of the samples was calcined at the same tempera- ture used in their preparation (300, 400, $600,750^{\circ} \mathrm{C}$ ) and another batch adsorption cycle was performed with the same dyestuff. Experiment was repeated 3 times and at the end of each cycle small portions of samples were collected and analyzed (BET, $X R D, U V e V i s$ and OEA). 
Adsorption capacities of the materials were then calculated according to Eq. (1). pseudo 2 nd order model [36]. Two models were fitted to the data obtained in equilibrium studies. The Langmuir's model [37] model and the Freundlich's model [38]. All models were fitted to the experimental data using non-linear regression. The parameters of models are presented with the respective confidence intervals at $95 \%$ confidence level. Variances and correlation coefficients were determined and compared using Fisher's, Akaike Information Cri- terion (AIC), and Bayesian Information Criterion (BIC) tests. Detailed models' description is given in the Supporting Materials.

\section{Results}

\subsection{Optimization of $\mathrm{pH}$ in adsorption studies}

The results obtained (Fig. 1) revealed differences in the maximum adsorption capacities depending on the temperature used during calcination and $\mathrm{pH}$ of the solution. The best treatment conditions were achieved at $450{ }^{\circ} \mathrm{C}$ and the optimal $\mathrm{pH}$ condition

for adsorption was 3.5 for AMB (Fig. 1A) and pH 8.0 for adsorption of AR (Fig. 1B). The samples treated that way exhibited good adsorption capacity towards the anionic dye (AMB) as well as satisfactory towards the cationic one $(A R)$. It was observed that the adsorption capacity decreased with increasing $\mathrm{pH}$ in the first case, however in case of the cationic dye the lowest capacities are observed for $\mathrm{pH}$ values of 7.0 and 8.0, except for HToxC450.

\section{Kinetics and equilibrium}

Adsorption studies were performed for kinetics and equilibrium for all systems at $\mathrm{pH} 3.5$, which is the optimal $\mathrm{pH}$ for AMB (Table A1). Experimental values and the respective model fits are represented in Fig. 2.

Similar experiments were performed for HToxC450, which was the material that presented higher capacities in Section 3.1, at pH

8.0 that is the optimal for adsorption of AR (Table A2). Kinetic and equilibrium experimental values and their model fits are shown in Fig. 3.

There was no difference in goodness of fit between the models at pH 3.5 and 8.0 according to Fisher's test, however AIC and BIC tests revealed that pseudo 2nd order model fitted better at $\mathrm{pH} 3.5$ and pseudo 1st order model at $\mathrm{pH}$ 8.0, for both dyes (Table A1). Adsorption of AMB at $\mathrm{pH} 3.5$ occurred at lower rate than adsorption of AR according to the pseudo 2nd order kinetic constant (Fig. 2A and B). At pH 8.0, where pseudo 1st order model was the best fit, the rate for AMB was higher than for AR (Fig. 3A). In the experiment conducted at $\mathrm{pH} 3.5$ the sample treated at $450{ }^{\circ} \mathrm{C}$ was the one with

the lowest rate for both dyes and needed approximately 120 min to reach the equilibrium for AMB and 50 min for AR. In other cases equilibrium was reached in approximately 60 and 30 min (Fig. $2 \mathrm{~A}$ and B). At pH 8.0 the adsorption equilibrium of $\mathrm{AMB}$ was reached approximately after $120 \mathrm{~min}$ and around $150 \mathrm{~min}$ was necessary for the equilibrium in case of $A R$ (Fig. 3A).

Adsorption equilibrium studies of $\mathrm{AMB}$ and $\mathrm{AR}$ at $\mathrm{pH} 3.5$, ac- cording to Fisher's AIC and BIC tests, followed the Langmuir's model. However at $\mathrm{pH}$ 8.0 Freundlich's model was a better fit for adsorption of AMB whereas adsorption of AR kept following the

Langmuir's model. All parameters of the models are presented in

${ }_{1 / 4}-{ }^{C} C_{0}-C_{e q}{ }^{\Sigma} V$ 
(1) Table A1 for $\mathrm{pH} 3.5$ and in Table $\mathrm{A} 2$ for $\mathrm{pH} 8.0$ in the Appendix.

Equilibrium experiments showed that the thermal treatment of the material resulted in an increase in its maximum adsorption where $q$ is adsorption capacity $\left(\mathrm{mg} \mathrm{g}^{-1}\right), C_{0}$ and $C_{e q}$ initial and equilibrium concentrations $\left(\mathrm{mg} \mathrm{L}^{-1}\right)$ respectively, $V$, volume of adsorbate $(\mathrm{L})$ and $m$, adsorbent mass $(\mathrm{mg})$.

To describe the adsorption kinetics two models were adjusted to the experimental data. The pseudo 1st order model [35] and the capacity for both dyes. The highest adsorption capacity was reached for the sample treated at $450{ }^{\circ} \mathrm{C}$ (Fig. $2 \mathrm{C}$ and D). Above

$450{ }^{\circ} \mathrm{C}$ the capacity decreased. The $\mathrm{pH}$ was the major factor affecting adsorption. At $\mathrm{pH} 3.5$ an increase from $179 \pm 5$ to $291 \pm 8 \mathrm{mg} \mathrm{g}^{-1}$ was noticed for $A M B$ and from $4.8 \pm 0.3$ to $31 \pm 5 \mathrm{mg} \mathrm{g}-1$ for AR. At pH 8.0 the capacity for AR increased to $48 \pm 2 \mathrm{mg} \mathrm{g}-1$ however, the material exhibited lower capacity for $\mathrm{AMB}$, which reached $178 \pm 17 \mathrm{mg} \mathrm{g}-1$ according to the Langmuir model (Fig. 3B)
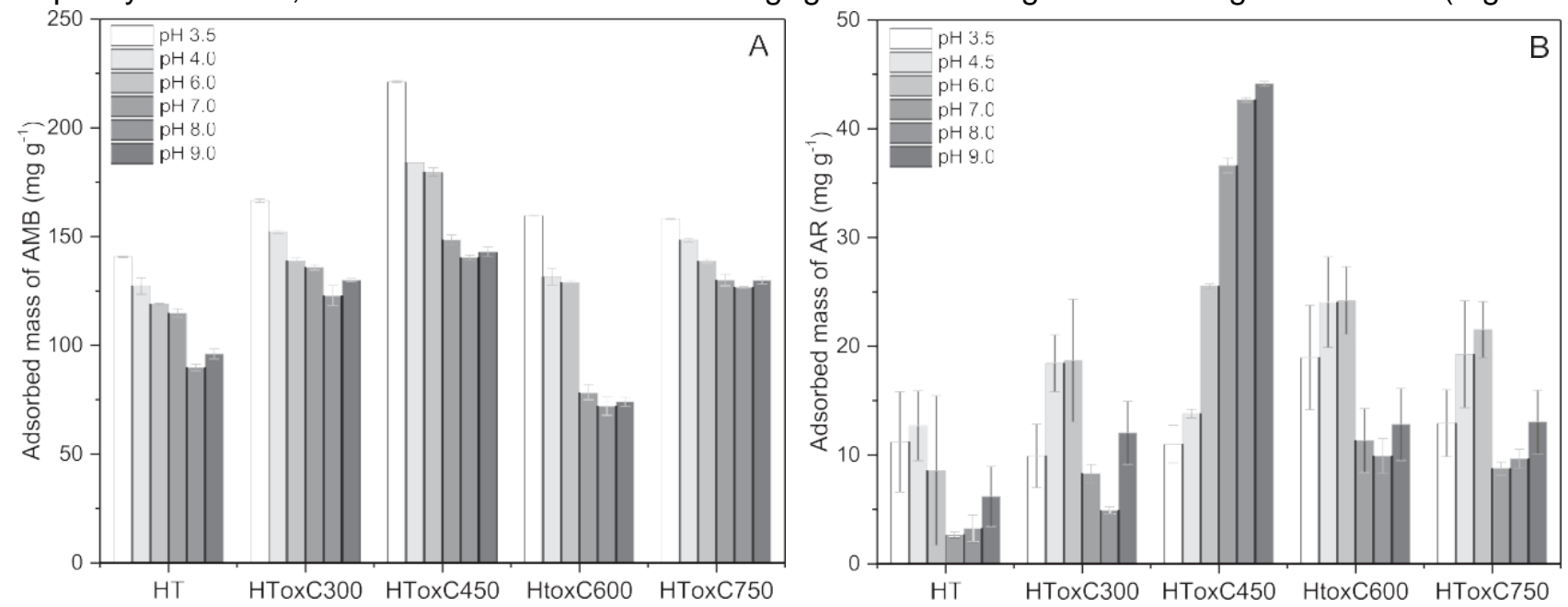

Fig. 1. Adsorption capacity of $A M B(A)$ and $A R(B)$ for different $\mathrm{pH}$ and thermal treatment conditions of hydrotalcite.
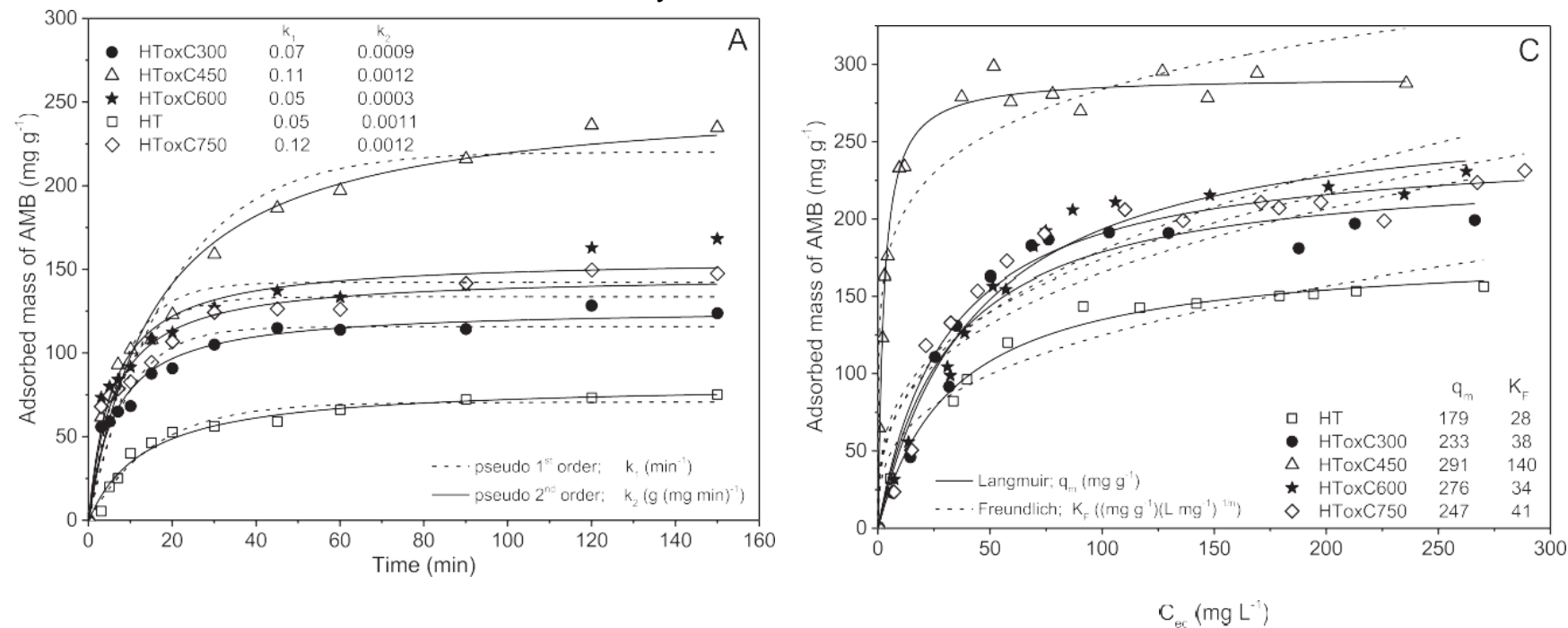

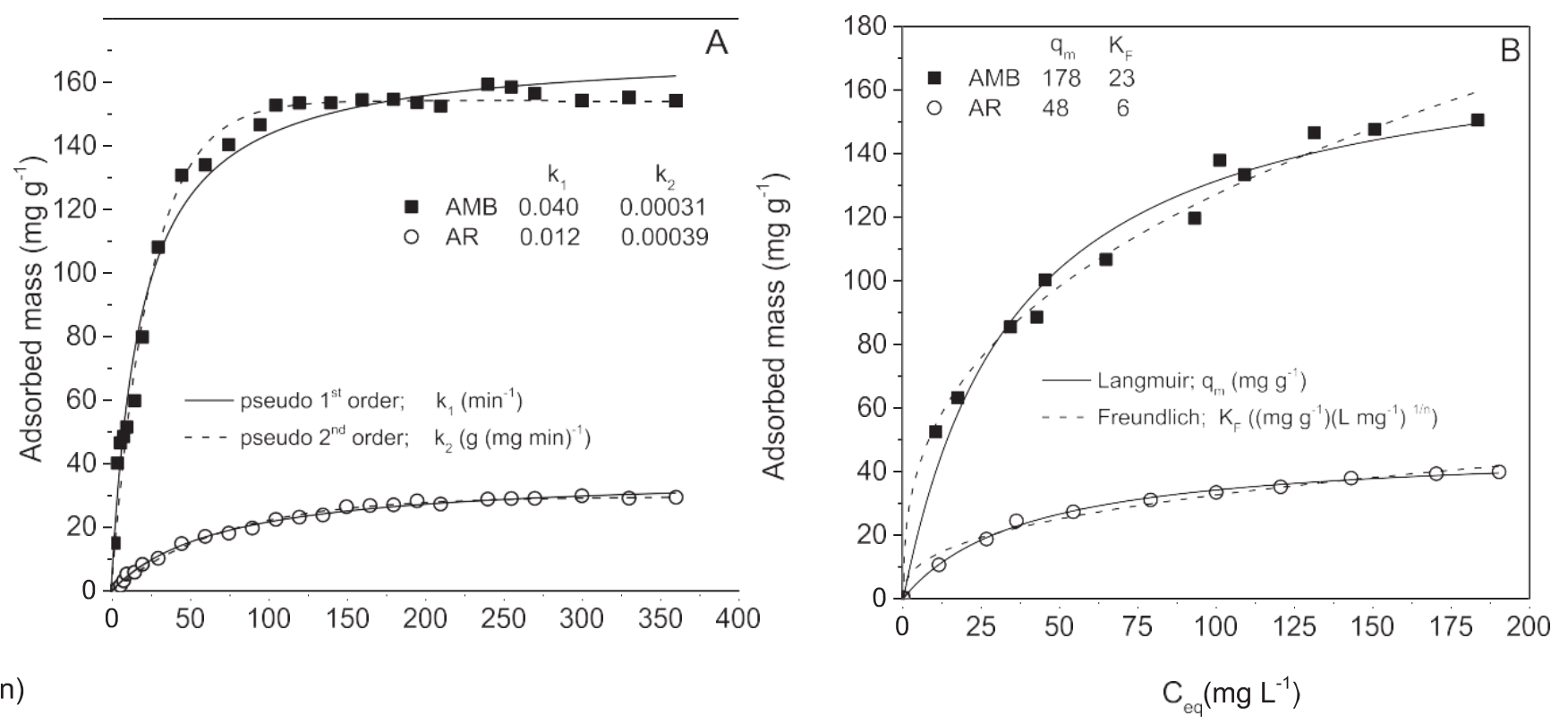

Fig. 2. Kinetic models and kinetic rate constants obtained for adsorption of $A M B(A)$ and $A R(B)$ and equilibrium models with respective parameters related to adsorption capacity of $A M B(C)$ and $A R(D)$ at $\mathrm{pH} 3.5$ for hydrotalcite and hydrotalcite-derived oxides.
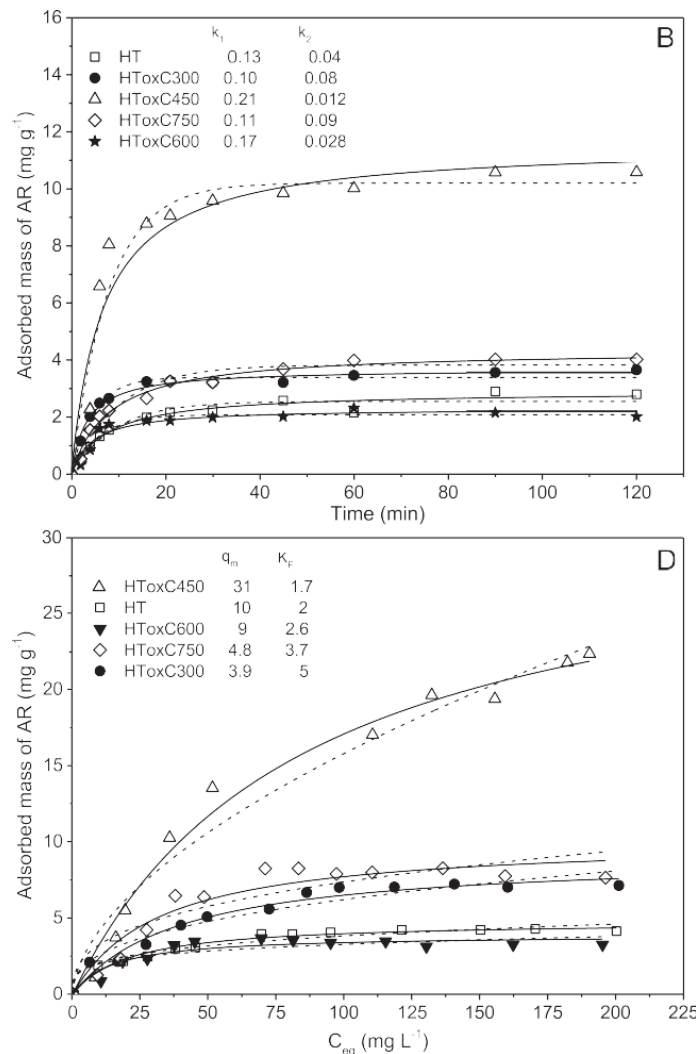

Fig. 3. Kinetic models with kinetic rate constants $(A)$ and equilibrium models with respective parameters related to adsorption capacity (B) obtained for adsorption of AMB and AR on HToxC45O at pH 8.o. 


\section{Regeneration of the spent adsorbents}

The regeneration of the spent adsorbents studies carried out with AMB showed that generally the adsorbent loses some of its

adsorption capacity after each cycle of regeneration with the loss being greater at lower pH (Fig. 4). The highest deterioration was in case of the sample calcineted at $300{ }^{\circ} \mathrm{C}$ where the capacity decreased after 3 cycles by $53 \%\left(88 \mathrm{mg} \mathrm{g}^{-1}\right)$ at $\mathrm{pH} 3.5$ and by $44 \%\left(61 \mathrm{mg} \mathrm{g}^{-1}\right)$ at $\mathrm{pH} 6.0$. The samples treated at 450 and 600 ${ }^{\circ} \mathrm{C}$ exhibited a loss of the adsorption capacity by $21 \%\left(47 \mathrm{mg} \mathrm{g}^{-1}\right)$ and by $31 \%\left(49 \mathrm{mg} \mathrm{g}^{-1}\right)$ at $\mathrm{pH} 3.5$ and by $15 \%\left(28 \mathrm{mg} \mathrm{g}^{-1}\right)$ and $22 \% \quad\left(28 \mathrm{mg} \mathrm{g}^{-1}\right)$ at $\mathrm{pH} 6.0$. The sample regenerated at $750{ }^{\circ} \mathrm{C}$ showed only a decrease after the first cycle by $35 \%\left(56 \mathrm{mg} \mathrm{g}^{-1}\right)$ at $\mathrm{pH} 3.5$ and $34 \%\left(48 \mathrm{mg} \mathrm{g}^{-1}\right)$ at $\mathrm{pH} 6.0$ and then the capacity remained on a stable level at both $\mathrm{pH}$ values (Fig. 4).

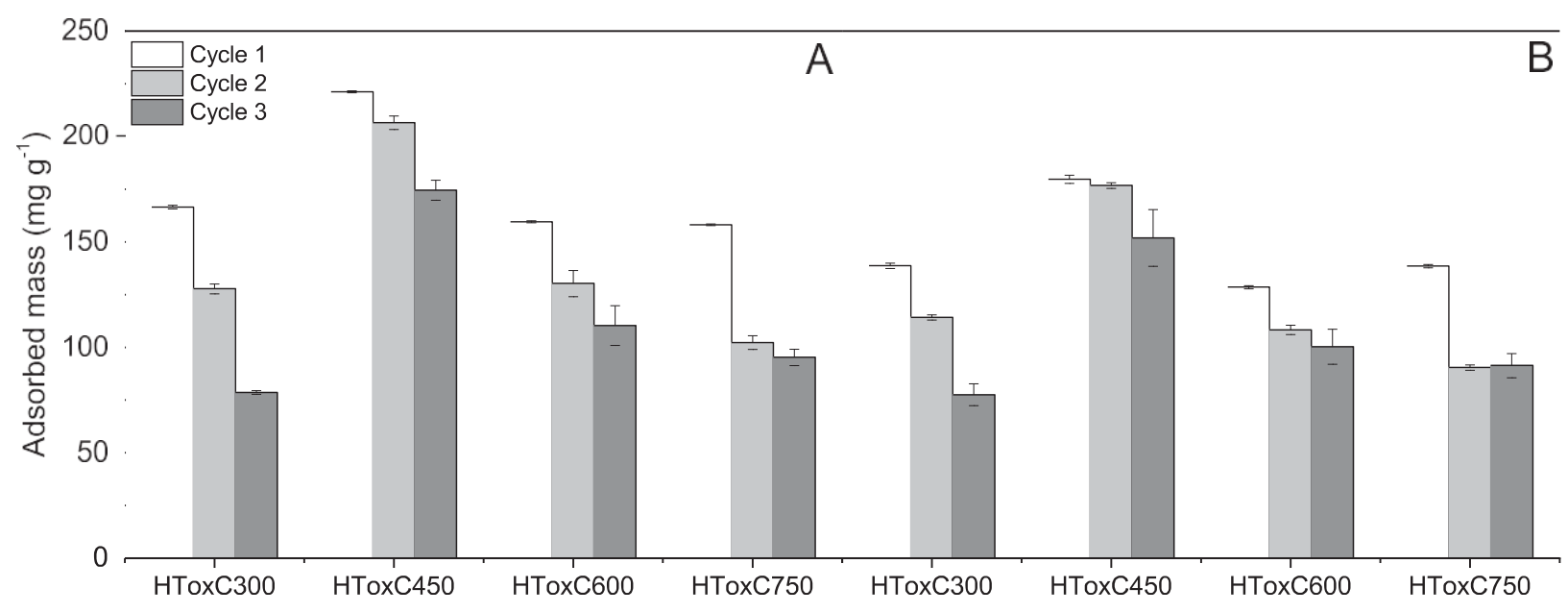

Fig. 4. Adsorption capacities of the materials in subsequent cycles of adsorption and regeneration in $\mathrm{pH} 3.5(\mathrm{~A})$ and $\mathrm{pH} 6.0(\mathrm{~B})$ 


\subsection{UVevis-diffuse reflectance spectroscopy (DRS)}

The dye in its solid state showed two peaks in the spectrum at around 380 and $555 \mathrm{~nm}$. The second peak shifted hypsochromati- cally to around $515 \mathrm{~nm}$ in case of hydrotalcite with adsorbed dye and the sample recalcined at $300{ }^{\circ} \mathrm{C}$. Further shift to around $535 \mathrm{~nm}$ was observed in samples treated at higher temperatures (Fig. S1E to S1I, Supporting material). This phenomenon known as meta- chromacy is ascribed to the formation of dye aggregates upon adsorption $[39,40]$ and to stacking interaction between the aggre-gated dyes in which dye's electron cloud can be attracted toward a polar group on the material's surface. This interaction lowers the energy of highest occupied molecular orbital (HOMO) while empty and lowest unoccupied molecular orbital (LUMO) remains unaf- fected creating a higher energy difference between the orbitals and the transition occurs at higher energy thus at shorter wave length $[41,42]$

The spectra of the samples calcined at 300 and $450{ }^{\circ} \mathrm{C}$ after adsorption showed 3 peaks at 315,360 and $400 \mathrm{~nm}$ that increased their intensity after each cycle of regeneration suggesting accu- mulation of partially decomposed dyes (Fig. S1A and S1B, Sup- porting material). In the sample calcined at $600{ }^{\circ} \mathrm{C}$ only after the

third calcination a small peak appeared (Fig. S1C, Supporting ma-terial). No signs of the dye were detected at $750{ }^{\circ} \mathrm{C}$ (Fig. S1D, Supporting material).

\section{Attenuated total reflectance infrared spectroscopy (ATR)}

In the spectra of the saturated materials several peaks that can be ascribed to vibrations of sulfonate groups (Fig. S2E, Supporting material) were found at 1224, 1182, 1126, 1083 and $1035 \mathrm{~cm}^{-1}[43,44]$. Those bands became more intense after each cycle of adsorption, especially the one located at $1030 \mathrm{~cm}^{-}$ 1. At the same time the band at around $1355 \mathrm{~cm}^{-1}$ with a shoulder at $1400 \mathrm{~cm}^{-1}$ and the peak at $860 \mathrm{~cm}^{-1}$ attributed to interlayer carbonate $[45,46]$

became less intensive. The spectra of the samples regenerated at $450{ }^{\circ} \mathrm{C}$ and higher temperature lost the band at around $775 \mathrm{~cm}^{-1}$ associated with lattice vibrations with metal hydroxide sheets [47] (Fig. S2E to S2I, Supporting material).

In the spectra of the samples regenerated at $300{ }^{\circ} \mathrm{C}$ the peaks

from the vibrations of sulfonate groups range still appear (Fig. S2A, Supporting material), however when a higher temperature was used for the regeneration the peaks in that range become broad, overlapped with a dominant peak at $1088 \mathrm{~cm}^{-1}$. The band at $1350 \mathrm{~cm}^{-1}$ disappeared together with appearance of the band at $1530 \mathrm{~cm}^{-1}$, which might be attributed to bicarbonates formed upon dehydratation due to proton transfer from the hydroxide sheets to carbonate ion [45]. The peak at around $1400 \mathrm{~cm}^{-1}$ remained but was overlapped by a band at $1420 \mathrm{~cm}^{-1}$ assigned to sulfate [48]. Similar phenomenon was observed in both investigated $\mathrm{pH}$ values,

3.5 and 8.0 (Fig. S2B to S2D, Supporting material).

\subsubsection{X-ray powder diffraction (XRD)}

Hydrotalcite showed typical reflections at $11.71^{\circ}\left(d_{003} 1 / 47.55 \AA\right.$ ), $23.31^{\circ}$ (do06 $1 / 4 \quad 3.82 \AA$ ), $34.8^{\circ}$ $\left(\begin{array}{llll}d_{009 p 012} & 1 / 4 & 2.57 & \AA\end{array}\right), \quad 39.40^{\circ}\left(d_{015} 1 / 42.29 \AA\right), 47.00^{\circ}\left(d_{018} 1 / 41.93 \AA\right), 60.90^{\circ}\left(d_{110} 1 / 41.52 \AA\right)$ and $62.19^{\mathrm{d} / 4}\left(\mathrm{~d}_{112} 1.49 \AA\right)$ [10] (Fig. S3E, Supporting material).

After adsorption, hydrotalcite successfully reconstructed its structure, however the reflections became less intensive after each cycle (Fig. S3F to S3I, Supporting material). In the samples after adsorption at $\mathrm{pH}$ 3.5 the cell parameter a, corresponding to the distance between two metal citations [10], was smaller which can be attributed to the selective leaching of $\mathrm{Mg}^{2 \mathrm{~b}}$ from the layers [49]. Also the parameter $c$, related to the thickness of the brucite-like layers, decreased at $\mathrm{pH} 3.5$ what can be correlated with increasing $x$ value, 


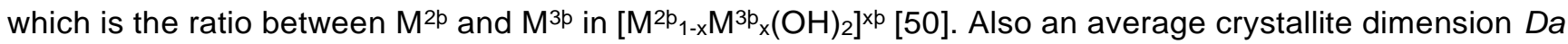
and $D c$, average crystallite size parallel to a crystallographic length unit $a$ and $c$, calculated using Sherrer equation, decreased upon each cycle and additionally it increases with calcination tempera- ture rise (Fig. $\mathrm{A} 3 \mathrm{~A}$ to $\mathrm{A} 3 \mathrm{D})$. At the same time the peaks after adsorption at $\mathrm{pH} 3.5$ were sharper than those at $\mathrm{pH} 6.0$ in case of

samples regenerated at 600 and $750{ }^{\circ} \mathrm{C}$ (Fig. S3H and S3I, Sup-

porting material). Those changes could suggest dissolution of the poor crystalline material of small crystallite diameter and leaching of $\mathrm{Mg}^{2 \mathrm{~b}}$ from the layers at lower $\mathrm{pH}$. Additionally, in the sample calcined at $600{ }^{\circ} \mathrm{C}$ $\mathrm{MgO}$ phase was present after the second and

third cycle of adsorption (Fig. $\mathrm{S} 3 \mathrm{H}$, Supporting material). At $\mathrm{pH} 6.0$ the $\mathrm{MgO}$ phase was quite uniform however, in case of lower $\mathrm{pH}$ the cell parameter a had a broader range and an increase in mean crystallite diameter was observed after each cycle and with increasing calcination temperature (Fig. A3E and A3F). In case of calcination at $750{ }^{\circ} \mathrm{C}$ together with $\mathrm{MgO}$ phase, spinel phase was present and gave reflection at $65^{\circ}$ after the first cycle and another sharper peaks at $19^{\circ}, 36.62^{\circ}$ and $44.6^{\circ}$ in the following cycles

(Fig. S3I, Supporting material). In this case the parameter a was similar for both $\mathrm{pH}$ values however, it decreased after each cycle and crystallite size increased (Fig. A3G and $\mathrm{A} 3 \mathrm{H}$ ) suggesting incomplete regeneration of hydrotalcite structure.

After heating at $300{ }^{\circ} \mathrm{C}$ the hydrotalcite phase was still present

in the sample and showed reflections at $12.5^{\circ}$ (d $d_{003} 1 / 47.08 \AA$ ), $25.2^{\circ}$ (do06 1/4 $3.53 \AA$ ), $34.50^{\circ}\left(d_{009} 1 / 42.60\right.$ $\AA$ ) and $60.82^{\circ}\left(d_{110} 1 / 41.52 \AA\right)$

(Fig. S3A, Supporting material and Fig. A1A to A1D). The 003 reflection shifted towards higher degrees. This shift together with the appearance of reflections at $36.00^{\circ}\left(d_{111} 1 / 42.49 \AA\right)$ and $43.30^{\circ}\left(d_{200} 2.09 \AA\right)$ suggest the creation of an intermediate dehydrated layered,phase related to dehydratation of the material by gradual

removal of interlayer water indicating a disorder in the stacking of the layers compared to the starting material [51]. After calcination at 450 and $600{ }^{\circ} \mathrm{C}$ only $\mathrm{MgO}$ phase was detected in the samples giving reflections at $35.20^{\circ}\left(d_{111} 1 / 42.55 \AA\right), 43.30^{\circ}\left(d_{200} 1 / 42.09 \AA\right)$ and $62.50^{\circ}\left(\mathrm{d}_{220} 1.48 \AA\right.$ ) (Fig. S3B and S3C, Supporting material). $\quad 1 / 4$ The $\mathrm{MgO}$ crystallite size remains stable in the range of lower temperatures and it increased at higher temperatures. This behavior is due to substitution of $\mathrm{Al}$ into the $\mathrm{MgO}$ lattice that occurs in a range of lower temperature which inhibits growth of the crystals [52]. Also due to the substitution the parameter a increased ( $\mathrm{Al}$ l3p has smaller cationic radius than $\mathrm{Mg}^{2 \mathrm{~b}}$ ) (Fig. A2E and $\mathrm{A} 2 \mathrm{~F}$ ). Moreover, the parameter $a$ is lower than in a pure $\mathrm{MgO}$ phase $\left(a^{1 / 4} 4.200 \AA\right)$, what also suggests that such substitution produces a solid solution [53]. The sample prepared at $600{ }^{\circ} \mathrm{C}$ exhibited more intensive and sharper peaks suggesting better crystallinity of the sample. After calcination at $750{ }^{\circ} \mathrm{C}$ a dominant phase was $\mathrm{MgAl}_{2} \mathrm{O}_{4}$ spinel giving reflections at $19.00^{\circ}\left(\begin{array}{llllll}d_{111} & 1 / 4 & 4.67 & \AA & \AA\end{array}\right), 31.00^{\circ}\left(d_{220} \frac{1 / 4}{}\right.$ $2.89 \AA), 36.62^{\circ}\left(d_{311} 1 / 42.45 \AA\right), 44.60^{\circ}\left(d_{400} \frac{1}{1 / 4} 2.03 \AA\right) 59.12^{\circ}$ $\left(d_{511} 1 / 41.56 \AA\right)$ and $65.00^{\circ}\left(d_{440} 1 / 41.43 \AA\right)$ accompanied by MgO with reflections at $43.10^{\circ}\left(d_{200} 2.10 \AA\right)$ and $62.62^{\circ}\left(d_{220} 1.48 \AA\right.$ ) [54] (Fig. S3D, Supporting material). The parameter a of spinel phase decreases in each cycle and with increasing temperature, crystallite

size increased in the process (Fig. A2G and $\mathrm{A} 2 \mathrm{H}$ ). When hydrotalcite is calcined in not too high temperature along with the elimination of hydroxyl and carbonate ions a non-stechiometric spinel-like phase might be formed with divalent ions trapped inside. At higher calcination temperatures excess of two-valent ions can migrate out of the spinel-like phase giving rise to formation of $\mathrm{M}(\mathrm{II}) \mathrm{O}$ and stechiometric spinel with lowering of the parameter $a$ and simul- taneous increase in crystallite size of the spinel [52].

The results of structural characterization of samples saturated with $R, A M B, C R, M O$ are shown in Fig. S4 (Supporting material). It was observed that intercalation proceeds differently for all studied dyes. In the case of both industrial dyes (R and $A M B$ ) and Congo Red obtained materials are characterized with significant loss of crys- tallinity resulting from poor stacking order and random organiza- tion of interlayer anions. On the other hand, well resolved peaks were identified for Methyl Orange intercalated hydrotalcite. 


\subsubsection{BET surface area}

The materials upon annealing in different temperatures exhibited diversity in their specific surface area. Generalty up to $600{ }^{\circ} \mathrm{C}$ the specific surface area increased and for higher temper-atures it decreased due to the creation of a spinel phase in the material (Fig. 5A). A slight but not such significant decrease in total pores' volume of the samples followed the same trend and reached their maximum value at $600{ }^{\circ} \mathrm{C}$ (Fig. 5B). Upon the following regeperation cycles the materials became less porous and their specific surface area generally decreased. It needs to be noticed that the samples annealed at $450{ }^{\circ} \mathrm{C}$ were characterized by the highest decrease in its specific surface area.

In measured isotherms (Fig. 6A) adsorption branch resembles type II isotherm, which is characteristic for nonporous or macro- porous materials [55], however in all samples hysteresis loops also appear. In starting materials after first calcination (C1), regardless the temperature, hysteresis loop is narrow and the thickness of the adsorbed $\mathrm{N}_{2}$ multilayer increases at $\mathrm{p} / \mathrm{p}_{0}$ values close to 1. This phenomenon corresponds to adsorption at external surface, which in the case of studied materials makes a large contribution (Fig. 5). After second and third cycle $(\mathrm{C} 2, \mathrm{C} 3)$ of regeneration hysteresis loop becomes broader, however, all shapes should be classified as type $\mathrm{H} 3$ or mixture of types $\mathrm{H} 3$ and $\mathrm{H} 2$. First type $(\mathrm{H} 3)$ usually is observed for non-rigid aggregates of plate-like particles and also if network of macropores is formed and not filled completely with condensate or other pore network effects play important role $(\mathrm{H} 2)$. In the pore size distribution, calculated using BJH model, two distinctive peaks corresponding to small and large mesopores are observed (Fig. 6B) as well as micropores (Fig. 5B). It was noticed that mesopore range is not affected significantly by low tempera-

ture of calcination $\left(300^{\circ} \mathrm{C}\right)$. At higher temperature $\left(450^{\circ} \mathrm{C}\right)$ suc-

cessive decrease of pore volume takes place and pores sintering $\left(600 \mathrm{e} 750{ }^{\circ} \mathrm{C}\right)$.
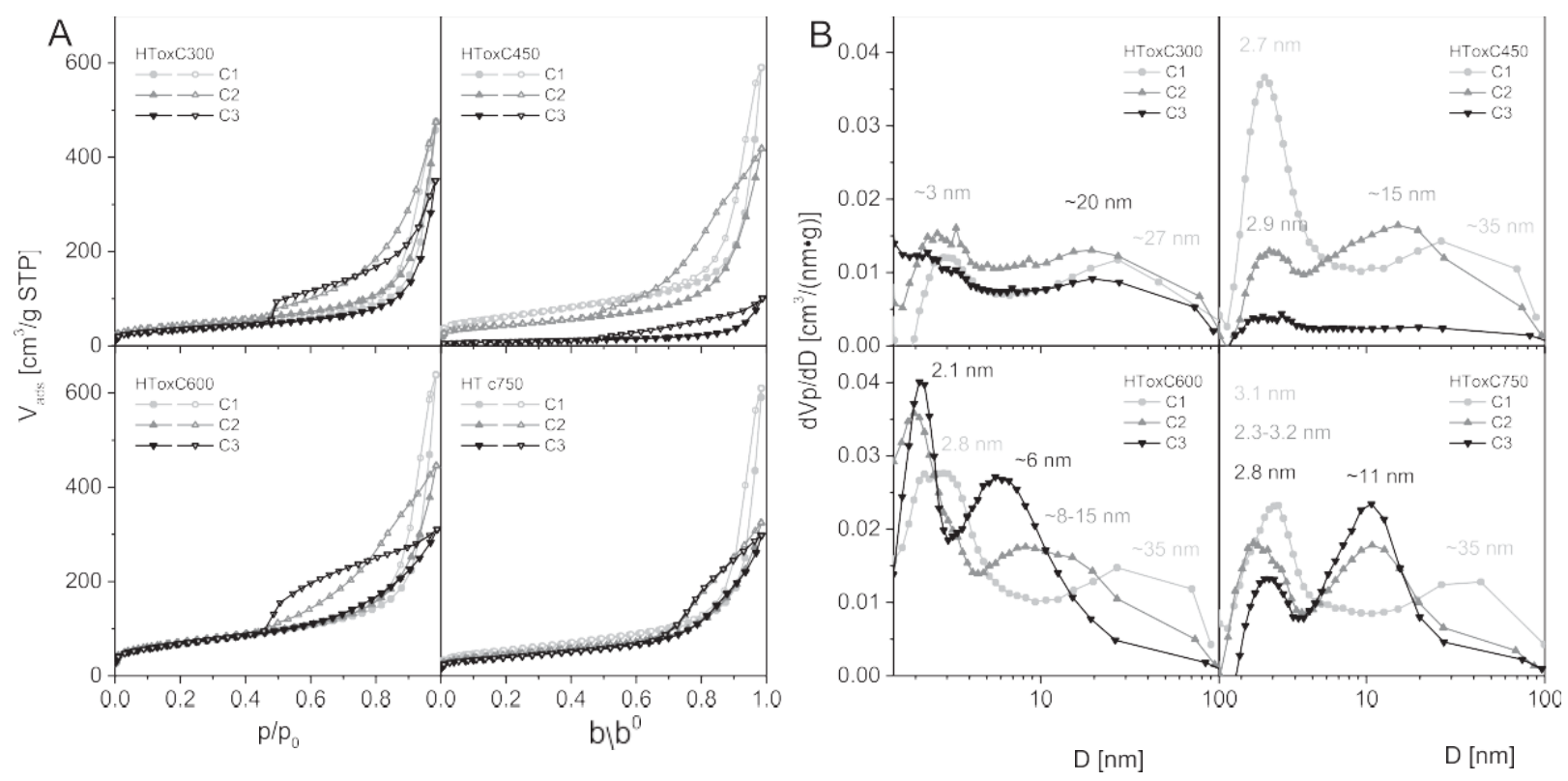

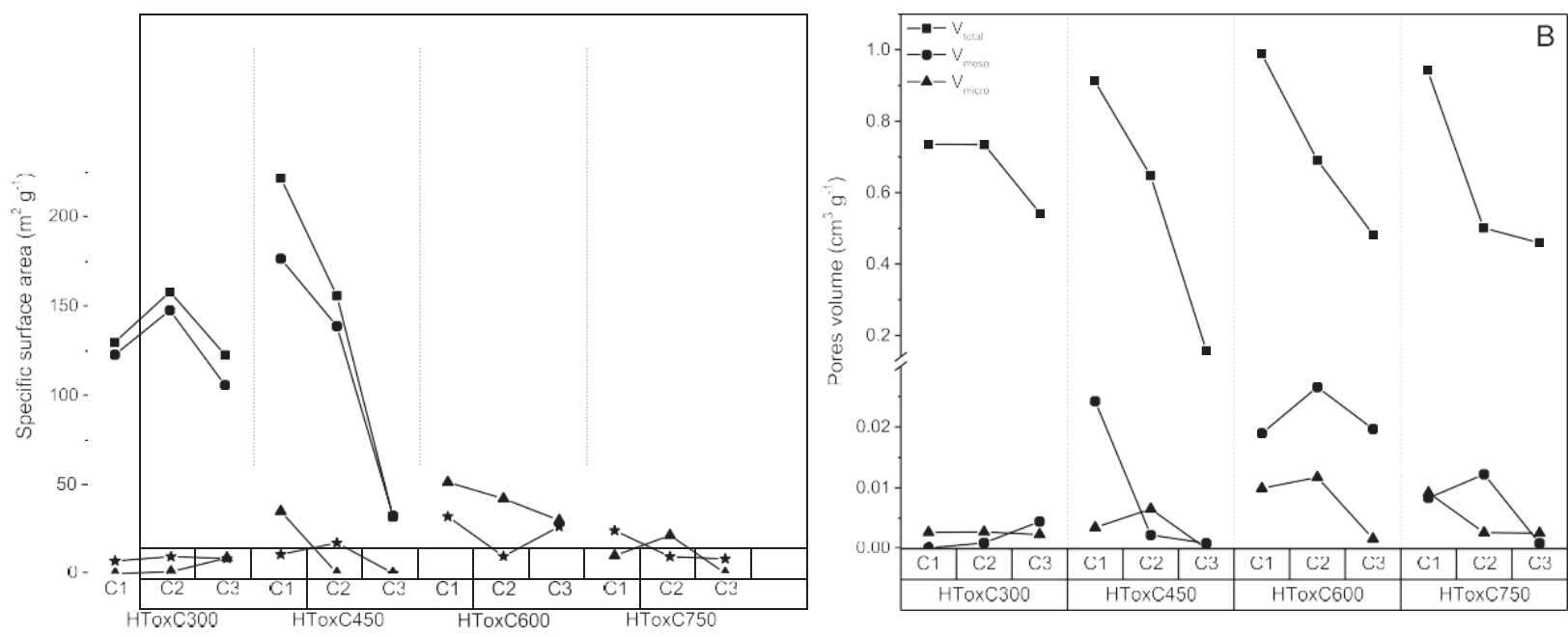

Fig. 5. Changes of pores' volume (A) and specific surface area $(B)$ of hydrotalcites calcined in different temperatures and following cycles of adsorption and regeneration.

Fig. 6. $\mathrm{N}_{2}$ adsorption-desorption isotherms measured in calcination-regeneration cycles (A), BJH distribution of mesopores for calcined hydrotalcites after adsorption of $A M B$ at $p H 1 / 43.5(B)$.

\subsubsection{Organic elemental analysis (OEA)}

The results showed that sulfur $(\mathrm{S})$ and nitrogen $(\mathrm{N})$ were accu-mulated in the samples. After the third cycle of regeneration the sample treated at $450{ }^{\circ} \mathrm{C}$ exhibited the highest level of sulfur while the sample regenerated at $300{ }^{\circ} \mathrm{C}$ was characterized by the highest content of nitrogen. At temperatures higher than $450^{\circ} \mathrm{C}$ no traces of nitrogen were found upon regeneration whilst sulfur was still present (Fig. 7A). The sample treated at the optimal temperature, $450{ }^{\circ} \mathrm{C}$, exhibited gradual accumulation of sulfur and nitrogen in

following cycles of adsorption (R1-R3). The nitrogen was success- fully eliminated upon regeneration and only traces were detected after the third cycle, however the content of sulfur significantly increased (Fig. 7B). The samples regenerated at 450 and $600{ }^{\circ} \mathrm{C}$ showed the highest difference in contents of $\mathrm{S}$ and $\mathrm{N}$, depending on the $\mathrm{pH}$ at which adsorption had been carried out. 


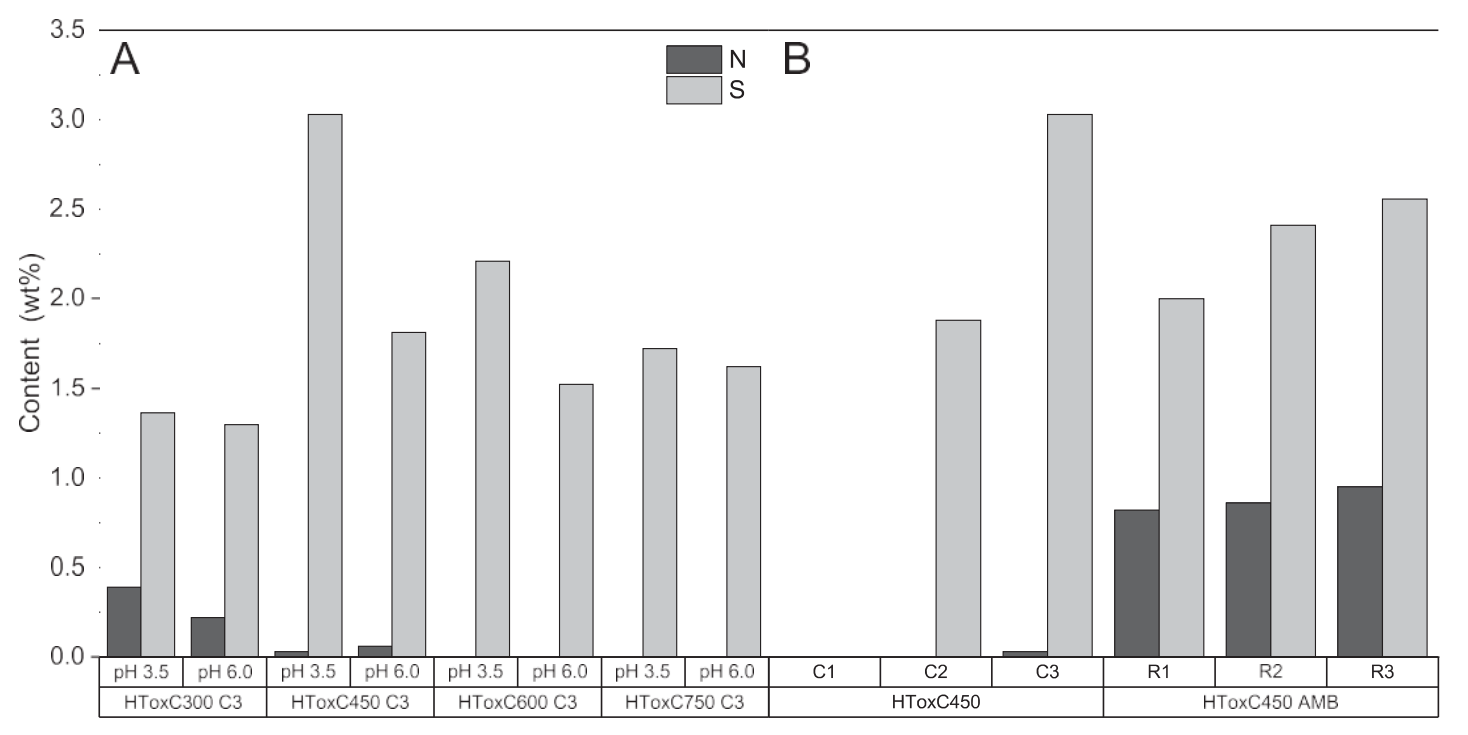

Fig. 7. Accumulation of $\mathrm{N}$ and $\mathrm{S}$ in the samples obtained after the third cycle of regeneration at different temperatures $(\mathrm{A})$ and accumulation of the elements in subsequent cycles of regeneration $\left(\mathrm{C} 2\right.$ e C3) and after adsorption of AMB (R1-R2) onto the sample treated at $450{ }^{\circ} \mathrm{C}(\mathrm{B})$.

\section{Discussion}

Each sample exhibited different adsorption behavior toward cationic and anionic dyes that was strongly influenced by the $\mathrm{pH}$ of the solutions. Two different groups of adsorption sites are present in the material: sites within the interlayer corresponding to the structural anion exchange capacity and adsorption sites on the external surface, and the chemical properties of those two are different [56]. The presence of two isolated electron pairs and a dissociable hydrogen on a surface hydroxyl group, indicates that these groups are potential ampholytes [57]. At low pH adsorption sites should be protonated what creates new sites for adsorption of anionic molecules thus adsorption of the anionic dye was pro- moted. In such conditions anions are adsorbed mainly by ligand exchange involving one or two surface hydroxyl groups [58]. Also migration in the interlayer space should be easier since carbonates present in it should be eliminated at lower $\mathrm{pH}$. At higher $\mathrm{pH}$ the situation reverses and adsorption of cationic molecules is privi- leged since the external adsorption sites are deprotonated and negatively charged. In such conditions cations are adsorbed by competitive complex formation involving one or two surface hy-droxyl groups [58]. Migration in-between the layers in case of the cationic dye is unlikely and adsorption takes place only in the outer surface, this could explain relatively low adsorption capacity for the cationic dye. It still needs to be noticed that despite unfavorable pH some quantity of AMB adsorbed at high $\mathrm{pH}$ and some $\mathrm{AR}$ was adsorbed at low $\mathrm{pH}$. This phenomenon can be explained by for- mation of type A or type $B$ ternary surface complexes. The first is created when cation is adsorbed between the surface and a ligand ( $A M B$ ) acquired from the solution phase (adsorption of $A R$ at low $p H$ ). The second is formed when an anion is adsorbed between the metal and the cation (adsorption of AMB at high $\mathrm{pH}$ ). Aside from the fact that the dye is incorporated in-between the layers while the hydrotalcite structure is reconstructed from the mixed oxide it also should be noticed that at high $\mathrm{pH}$ some of the interlayer car- bonates that are the most important limiting factor for the anion exchange reaction [56] might be exchanged with $\mathrm{OH}$, which sub- sequently are exchanged by an AMB anions.

Thermal treatment of hydrotalcite resulted in formation of mixed oxides of different phase composition depending on the temperature used. After annealing at $300{ }^{\circ} \mathrm{C}$ hydrotalcite phase however, of decreased crystallinity, was still present in the sample together with dehydrated layered phase. Treatment at 450 and $600{ }^{\circ} \mathrm{C}$ totally transformed hydrotalcite phase into mixed oxides and at 
$750{ }^{\circ} \mathrm{C}$ it was additionally created a spinel phase in the product. After adsorption hydrotalcite was successfully regenerated in all samples but it was the less crystalline in case of the sample treated at $450^{\circ} \mathrm{C}$. The sample treated at $750^{\circ} \mathrm{C}$ after adsorption still exhibited presence of a spinel and a mixed oxide phase (Fig. S3, Supporting material). The temperature of $450{ }^{\circ} \mathrm{C}$ was found to be the optimal in terms of adsorption capacity and ability of adsorbing both types of dyes (Fig. 1). The best adsorption properties of the sample prepared at $450{ }^{\circ} \mathrm{C}$ might be attributed to its specific composition. The surface of dry oxides is characterized by the presence of metal ions that are not fully coordinated which gives rise to Lewis acidity. The presence of water leads in the first step to coordination of water molecules, dissociative chemisorption and formation of surface hydroxyl groups. Due to various feasible coordinative environments of metal ions in hydrated surfaces hy- droxyl groups might not be chemically equivalent what in turn reflects in major differences in their chemical properties. Moreover it is very likely that a given oxide carries different types of surface hydroxyls [58] thus this contributes to different adsorption prop-erties of the materials. Moreover, specific surface area of that

sample greatly increased compared to the sample treated at $300{ }^{\circ} \mathrm{C}$

however it was not as high as for the sample treated at $600^{\circ} \mathrm{C}$, but it showed similar total pores volume nevertheless with bigger contribution of mesopores (Fig. 5). If adsorption should take place aside from interlayer space, i.e. on the outer surface of the material, such should be enhanced due to formation of mesopores that may be more accessible to bulk molecules like dyes than microspores.

The individual shape of hysteresis loop depends on processes taking place at a given temperature. In the case of the samples calcined at $300{ }^{\circ} \mathrm{C}$, it should be expected that hydrotalcite platelets are preserved and incomplete dehydration takes place after calci- nation. Steep decrease of volume adsorbed close to $\mathrm{p} / \mathrm{p}_{0} \quad 0.45$

could be explained by cavitation-induced evaporation taking place in metastable fluid present in slit-like pores (type $\mathrm{H} 2(\mathrm{a})$ ) [59]. $\mathrm{N}_{2}$ isotherms for the samples after second cycle of regeneration and calcination at temperature range $450 \mathrm{e} 600^{\circ} \mathrm{C}$, are characterized with not so sharp desorption branch, located at higher $\mathrm{p} / \mathrm{p}_{0}$ values.

This temperature range is sufficient to transform hydrotalcite into mixed metal oxide and spinel, and additionally, as it was shown in chapter 4.4.5, accumulation of decomposition products occurs. It should be expected that complex network of pores is formed, and observed shape of hysteresis loop, which could be assigned as $\mathrm{H} 2(\mathrm{~b})$, is results of pore blocking. Moreover, pore size distribution

of pore necks is wider than in the case of the sample obtained at $300{ }^{\circ} \mathrm{C}$. Both samples obtained after third cycle of calcination at 450 and $600{ }^{\circ} \mathrm{C}$ contain mixture of pores and effects described above, however, due to much higher clogging by decomposition products

at $450{ }^{\circ} \mathrm{C}$, the isotherm is located at lower adsorption values. As it was shown in chapter 4.4 .4 , at temperature $600 \mathrm{e} 750{ }^{\circ} \mathrm{C}$, meso- pores are still present, however their size is reduced, especially large pores. Unlike low temperatures, that are not enough to decompose completely hydrotalcite $\left(300{ }^{\circ} \mathrm{C}\right)$ or remove adsorbate $\left(450^{\circ} \mathrm{C}\right)$, observed at higher temperatures mesopores could be associated with porous network of mixed oxide.

The adsorption kinetics at pH 3.5 followed the pseudo 2nd order model in case of both dyes. For AMB the adsorption rate on all materials that were characterized by relatively low adsorption ca-

pacity is statistically the same, however in case of the samples treated at $450{ }^{\circ} \mathrm{C}$ it is lower by an order of magnitude. That might confirm creation of additional adsorption sites and specific porous structure of the sample that rendered the adsorption slower but

higher. At the same time the adsorption rate of $\mathrm{AR}$ at this $\mathrm{pH}$ was faster than adsorption of $\mathrm{AMB}$ and no statistically significant dif- ferences between the rates were observed for the starting material and sample treated at 300 and $600{ }^{\circ} \mathrm{C}$. However, for the sample treated at $450{ }^{\circ} \mathrm{C}$ the rate was again the lowest and a decrease was noticed on sample treated at $750{ }^{\circ} \mathrm{C}$. It is to be noticed that at higher $\mathrm{pH}$ the mechanisms changed and pseudo 1st order model fits better in both cases, with adsorption rate of AMB being higher than of AR. This can be explained by better access to the sites (Table A1 and A2). AMB should encounter 
competition with $\mathrm{OH}^{-}$ions present in the solution and the exchange with interlayer anion should be impar-

ted however, AR as it is a cation can adsorb on available deproto- nated surface groups.

The equilibrium experiment indicated Langmuir's model as the best fit for adsorption of both dyes at $\mathrm{pH}$ 3.5. Adsorption of $\mathrm{AR}$ at $\mathrm{pH}$

8.0 also followed Langmuir's model however, for $\mathrm{AMB}$ at this $\mathrm{pH}$ the Freundlich's model was a better fit (Table A1 and A2). This model assumes adsorption on heterogeneous surfaces, oppositely to Langmuir's model. While at low $\mathrm{pH}$ all the adsorption sites are protonated rendering the surface quite homogenous, at $\mathrm{pH}$ equal

8.0 the sites should be mostly deprotonated but some of them might still be protonated making the surface heterogeneous. Moreover there must be a competition between $\mathrm{AMB}$ and $\mathrm{OH}^{-}$anions for adsorption sites that makes homogeneous coverage of the surface by AMB less likely.

The regeneration studies of the spent adsorbent revealed that after each cycle adsorption/regeneration a loss of adsorption ca- pacity of the material was noticed (Fig. 4A and B). This phenome- non is related to changes occurring in the samples after each cycle of adsorption and regeneration. The hydrotalcite reconstructed from calcined sample became less crystalline after each cycle since various kinds of disorders might be incorporated during crystalli- zation of hydrotalcite. They lead to stacking faults that give rise to broad asymmetric reflections acquiring a "saw tooth" or "shark's fin" line shape in the XRD patterns [60] (Fig. S2, Supporting ma- terial). The loss in maximum adsorption capacity was correlated with temperature used during regeneration. The highest deterio-

ration was noticed in the sample treated at $300{ }^{\circ} \mathrm{C}$ and the lowest at

$600{ }^{\circ} \mathrm{C}$. When $750{ }^{\circ} \mathrm{C}$ temperature was applied during treatment the adsorption capacity of the material deteriorated more. The application of higher temperatures caused formation of additional phases in the material e.g. spinel in case of $750{ }^{\circ} \mathrm{C}$ and $\mathrm{MgO}$ in case of $600{ }^{\circ} \mathrm{C}$ that were not able to fully recreate hydrotalcite in adsorption cycle and caused loss of some of the adsorption capacity.

Another important cause of changes in the adsorption capacity was accumulation of products of decomposition of the dye. It was observed that at $300^{\circ} \mathrm{C}$ some nitrogen and sulfur compounds were

still present in the sample. With rising regeneration temperature the amount of nitrogen detected in the samples decreased and disappeared when $600{ }^{\circ} \mathrm{C}$ or higher temperatures were used (Fig. S2, Supporting material and Fig. 7) however, sulfur was pre-sent regardless the temperature. Also UVeVis analysis confirmed

that those temperatures were able to remove the decomposition products more efficiently and peaks from colored compounds dis- appeared (Fig. S1, Supporting material).

The accumulation of sulfates, although it contributes to the decrease in the maximum adsorption capacity, is actually a desired phenomenon. It prevents such compounds that have negative ef- fect on the environment and human health [61], Ayres [62] Win- terdahl et al. [63] from being released in large amounts into the environment in the course of regeneration process. As they are adsorbed on the adsorbent they may be desorbed after several cycles of utilization of the material and giving concentrated solu- tion that may be safely disposed of. However, this feature requires further research.

Thermal decomposition of hydrotalcite led to the formation of high surface area products. The highest specific surface area was achieved after calcination at $600{ }^{\circ} \mathrm{C}$. The total pore volume was similar in samples treated at $450{ }^{\circ} \mathrm{C}$ and higher, however, the sample treated at $600{ }^{\circ} \mathrm{C}$ had better developed microporosity than the sample treated at $450{ }^{\circ} \mathrm{C}$. Hydrotalcite-like compounds during thermal modification undergo textural modification attributed to a topotactic transformation where the interparticle porosity in- creases due to their reorganization during calcination. Also a part of the porosity is attributed to so called cratering effect due to expulsion of interlayer anion and water during the process of thermal treatment [64]. The sample annealed at $750{ }^{\circ} \mathrm{C}$ was char- acterized by lower specific surface area which might be attributed to formation of the spinel phase (Fig. 6). In following cycles of regeneration/adsorption both the porosity and specific surface area decreased in all samples. It is most likely the sulfur remaining in the samples after the calcination blocks up the pores and causes the decrease [65]. Sulfates can also show a tendency toward grafting with brucite-like layers rendering the internal surface of the ma- terial inaccessible [66]. The most 
significant decrease in the specific surface area was noticed for the samples annealed at $450{ }^{\circ} \mathrm{C}$. In any case, the temperature of $450{ }^{\circ} \mathrm{C}$ is the best condition for adsorbent regeneration because it prevents fast transformation from quasi- amorphous mixed metal oxide, characterized with structural memory and ability to reconstruct a hydrotalcite phase, into a

stable mixed oxide which cannot incorporate significant amount of anions during the regeneration process. This sample had the highest adsorption capacity thus it should have the highest amount of products of the decomposition of the dye. When the samples are regenerated the obtained mixed oxides must be somehow clogged and cemented by the dyes residues. $\mathrm{N}_{2}$ adsorption method creates limitations due to the relatively large van der Waals radius of the $\mathrm{N}_{2}$ molecule that prevents it from interacting with surface functional group occluded in small void spaces inaccessible due to the presence of sulfates and it is adsorbed only on the most accessible surfaces [67]. However, the structure of the clusters may be broken in the solution, the hydrotalcite is regenerated and adsorption can proceed.

The analysis of the spent adsorbents saturated with excess with four dyes gave insight on the orientation of adsorbed dye. Usually dyes are large organic molecules and it is expected that in the interlayer space they occupy a larger area than the one associated with one layer charge. In the case of the adsorbent used for pre- sented studies this area is equal $0.24 \mathrm{~nm}^{2}$ and it is significantly smaller than dimensions (cross sections) of studied molecules (Table A3). In such case rearrangement of anions occur from flat- lying to tilt-lying or orientation perpendicular to the brucite-like

layer $[56,68,69]$. It was shown that, in specific conditions of high adsorbate excess, cell parameters increased due to described phe- nomenon for all dyes but one e Reactive Red 184. Because detailed information about molecular design of industrial dyes is not always available, we may predict on the basis of obtained XRD patterns, behavior of studied adsorbates. There is no large increase of cell parameter in the case of $\mathrm{R}$ intercalated hydrotalcite, probably as a result of low affinity toward adsorbent and for this dye it should be expected only limited removal degree. For AMB an expansion of interlayer space occurs, giving rise to interlayer distance similar to $\mathrm{MO}$. Therefore we may conclude that $A M B$ is not a very large molecule. However, much larger broadening of XRD peaks indicates that there are no such strong interactions between dye molecules, as in the case of MO via p-p interactions of phenyl groups [70].

Dimensions of both dyes (CR and $\mathrm{MO}$ ) correspond very well with the height of interlayer gallery, but in the case of Congo Red anions they are most probably tilted.

\section{Conclusions}

Thermal treatment of hydrotalcite resulted in formation of mixed oxides characterized by high adsorption capacity and high specific surface area. Application of various temperatures in the calcination process resulted in formation of material characterized by different adsorption properties.

Annealing at $450{ }^{\circ} \mathrm{C}$ gave the best material in terms of adsorption capacity toward both anionic and cationic dyes. The capacity increased from $179 \pm 5$ to $291 \pm 8 \mathrm{mg} \mathrm{g}^{-1}$ in case of the anionic dye at $\mathrm{pH} 3.5$ and from $6 \pm 2$ to $48 \pm 2 \mathrm{mg} \mathrm{g}^{-1}$ in case of the cationic dye at $\mathrm{pH} 8.0$, on starting and thermally treated material at $450^{\circ} \mathrm{C}$, respectively according to the equilibrium experiments. Adsorption exhibited strong $\mathrm{pH}$ depen- dence. The anionic dye was more efficiently removed at lower $\mathrm{pH}$ equal 3.5 whilst the adsorption of the cationic dye was favored at

higher $\mathrm{pH}$ values, 8.0. Studies on regeneration of the adsorbent revealed that thermal treatment may be successfully applied for that purpose. Small loss of adsorption capacity was observed, which was associated with accumulation of the product of decomposition of previously adsorbed dye (i.e. sulfur compounds).

Thermal regeneration in optimum conditions of $450{ }^{\circ} \mathrm{C}$ is beneficial

in terms of protection of the environment since it prevents the release of potentially hazardous substances. Those are stored in the adsorbent and might be further extracted and safely neutralized.

Partial decomposition of dyes, which occurred at $450{ }^{\circ} \mathrm{C}$, did not 
impede adsorption process, on the contrary to the harsher condi- tions $\left(600{ }^{\circ} \mathrm{C}\right)$ resulting in total incineration of organic molecules. Therefore, accumulation and storage of potentially toxic products of the dyestuffs degradation is rather beneficial than unfavorable

phenomenon shown by hydrotalcite-derived adsorbents.

\section{Acknowledgements}

This work is financed by Fundos FEDER from Programa Oper- acional Factores do Competitividade (COMPETE) and Fundos Nacionais from Fundaçao para a Ciência e a Tecnologia (FCT) within the scope of the project SFRH/BD/80537/2011 and by the European Union (FEDER funds through COMPETE) and National Funds (FCT),

through project Pest-C/EQB/LA0006/2013. Part of the research was carried out with the equipment purchased thanks to the financial support of the European Regional Development Fund in the framework of the Polish Innovation Economy Operational Program (contract no. POIG.02.01.00-12023/08). To all financing sources the authors are greatly indebted. 


\section{References}

[1] H. Leube, in: K. Hunger (Ed.), Industrial Dyes: Chemistry, Properties, Appli- cations, Wiley, Germany, 2007.

[2] R. Kant, Textile dyeing industry an environmental hazard, Nat. Sci. 4 (1) (2012) 22e26.

[3] P.K. Mondal, B. Chauhan, in: E. Lichtfouse, J. Schwarzbauer, D. Robert (Eds.), Environmental Chemistry for a Sustainable World, Springer, 2012.

[4] L. Pereira, M. Alves, in: A. Malik, E. Grohmann (Eds.), Environmental Protection Strategies for Sustainable Development, Springer Science \& Business Media, 2011.

[5] U. Sevekow, in: K. Hunger (Ed.), Indystrial Dyes. Chemistry, Properties, Ap- plications, Wiley-Vch, Weinheim, 2003.

[6] I. Ali, M. Asim, T.A. Khan, Low cost adsorbents for the removal of organic pollutants from wastewater, J. Environ. Manag. 113 (0) (2012) 170e183.

[7] B. Pan, B. Pan, W. Zhang, L. Lv, Q. Zhang, S. Zheng, Development of polymeric and polymer-based hybrid adsorbents for pollutants removal from waters, Chem. Eng. J. 151 (1e3) (2009) 19e29.

[8] F. Rozada, L.F. Calvo, A.I. Garcıa, J. Martın-Villacorta, M. Otero, Dye adsorption by sewage sludgebased activated carbons in batch and fixed-bed systems, Bioresour. Technol. 87 (3) (2003) $221 \mathrm{e} 230$.

[9] V. Rives, in: V. Rives (Ed.), Layered Double Hydroxides: Present and Future, Nova Science Publishers, Inc., New York, 2006.

[10] A. de Roy, C. Forano, J.P. Besse, in: V (Ed.), Layered Double Hydroxides: Present and Future Rives, Nova Science Publishers, Inc., New York, 2006.

[11] B. Li, Y. Zhang, X. Zhou, Z. Liu, Q. Liu, X. Li, Different dye removal mechanisms between monodispersed and uniform hexagonal thin plate-like MgAleCO32eLDH and its calcined product in efficient removal of Congo red from water, J. Alloys Compd. 673 (2016) 265e271.

${ }_{\text {[12] }}$ E. Heraldy, S.J. Santosa, T. Triyono, K. Wijaya, Anionic and cationic dyes removal from aqueous solutions by adsorption onto synthetic $\mathrm{mg} / \mathrm{al}$ hydrotalcite-like compound, Indones. J. Chem. 15 (3) (2015).

[13] R.-r. Shan, L.-g. Yan, Y.-m. Yang, K. Yang, S.-j. Yu, H.-q. Yu, B.-c. Zhu, B. Du, Highly efficient removal of three red dyes by adsorption onto MgeAl-layered double hydroxide, J. Ind. Eng. Chem. 21 (2015) 561 e568.

[14] C. Zhang, S. Yang, H. Chen, H. He, C. Sun, Adsorption behavior and mechanism of reactive brilliant red X-3B in aqueous solution over three kinds of hydrotalcite-like LDHs, Appl. Surf. Sci. 301 (2014) 329e337.

[15] M. Mustapha Bouhent, Z. Derriche, R. Denoyel, V. Prevot, C. Forano, Ther- modynamical and structural insights of orange II adsorption by MgRAINO3 layered double hydroxides, J. Solid State Chem. 184 (5) (2011) 1016e1024.

[16] R.M.M. Santos, R.G.L. Gonçalves, V.R.L. Constantino, L.M. da Costa, L.H.M. da Silva, J. Tronto, F.G. Pinto, Removal of Acid Green 68:1 from aqueous solutions by calcined and uncalcined layered double hydroxides, Appl. Clay Sci. 80e81 (2013) $189 \mathrm{e} 195$.

[17] R. Extremera, I. Pavlovic, M.R. Pérez, C. Barriga, Removal of acid orange 10 by calcined $\mathrm{Mg} / \mathrm{Al}$ layered double hydroxides from water and recovery of the adsorbed dye, Chem. Eng. J. 213 (2012) 392e400.

[18] T.P.F. Teixeira, S.I. Pereira, S.F. Aquino, A. Dias, Calcined layered double hy- droxides for decolorization of azo dye solutions: equilibrium, kinetics, and recycling studies, Environ. Eng. Sci. 29 (7) (2012) 685e692.

[19] J. Flores, E. Lima, M. Maubert, E. Aduna, J.L. Rivera, Clean-up of wastes from the textile industry using anionic clays, Clays Clay Miner. 58 (3) (2011).

[20] L. El Gaini, M. Lakraimi, E. Sebbar, A. Meghea, M. Bakasse, Removal of indigo carmine dye from water to MgeAleCO3-calcined layered double hydroxides, J. Hazard. Mater. 161 (2e3) (2009) 627 e632.

[21] N. Drici Setti, N. Jouini, Z. Derriche, Sorption study of an anionic dye e ben- zopurpurine 4B e on calcined and uncalcined MgeAl layered double hy- droxides, J. Phys. Chem. Solids 71 (4) (2010) 556e559.

[22] A.R. Auxilio, P.C. Andrews, P.C. Junk, L. Spiccia, The adsorption behavior of C.I. Acid Blue 9 onto calcined MgeAl layered double hydroxides, Dyes Pigments 81 (2) (2009) 103e112. 
[23] G. Bascialla, A.E. Regazzoni, Immobilization of anionic dyes by intercalation into hydrotalcite, Colloids Surfaces A Physicochem. Eng. Aspects 328 (1e3) (2008) 34e39.

[24] M.-X. Zhu, Y.-P. Li, M. Xie, H.-Z. Xin, Sorption of an anionic dye by uncalcined and calcined layered double hydroxides: a case study, J. Hazard. Mater. 120 (1e3) (2005) 163e171.

[25] M. Bouraada, F. Belhalfaoui, M.S. Ouali, L.-C. de Ménorval, Sorption study of an acid dye from an aqueous solution on modified MgeAl layered double hy- droxides, J. Hazard. Mater. 163 (1) (2009) $463 e 467$.

[26] J. Orthman, H.Y. Zhu, G.Q. Lu, Use of anion clay hydrotalcite to remove col- oured organics from aqueous solutions, Sep. Purif. Technol. 31 (1) (2003) 53 e59.

[27] J. Das, B. Sairam Patra, N. Baliarsingh, K.M. Parida, Calcined MgeFeeCO3 LDH as an adsorbent for the removal of selenite, J. Colloid Interface Sci. 316 (2) (2007) $216 \mathrm{e} 223$.

[28] C. Barriga, M. Gaitan, I. Pavlovic, M.A. Ulibarri, M.C. Hermosin, J. Cornejo, Hydrotalcites as sorbent for 2,4,6-trinitrophenol: influence of the layer composition and interlayer anion, J. Mater. Chem. 12 (4) (2002) 1027e1034.

[29] E.L. Crepaldi, J. Tronto, L.P. Cardoso, J.B. Valim, Sorption of terephthalate an- ions by calcined and uncalcined hydrotalcite-like compounds, Colloids Sur- faces A Physicochem. Eng. Aspects 211 (2e3) (2002) 103e114.

[30] N.K. Lazaridis, Sorption removal of anions and cations in single batch systems by uncalcined and calcined Mg-Al-CO3 hydrotalcite, Water, Air, Soil Pollut. 146 (1) (2003) 127e139.

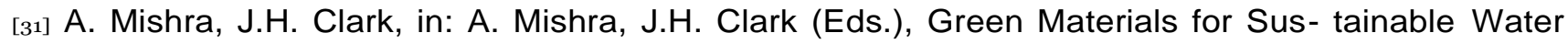
Remediation and Treatment, Royal Society of Chemistry, 2013.

[32] T.P.F. Teixeira, S.F. Aquino, S.I. Pereira, A. Dias, Use of calcined layered double hydroxides for the removal of color and organic matter from textile effluents: kinetic, equilibrium and recycling studies, Braz. J. Chem. Eng. 31 (2014) $19 e 26$.

[33] T.T. Teng, L.W. Low, in: S.K. Sharma, R. Sanghi (Eds.), Advances in Water Treatment and Pollution Prevention, Springer, Netherlands, 2012.

[34] R.K. Sharma, in: A. Mishra, J.H. Clark (Eds.), Green Materials for Sustainable Water Remediation and Treatment, Royal Society of Chemistry, 2013.

[35] S. Lagergren, About theory of so-called adsorption of soluble substances, Kongl. Vetenskaps Acad. Handl. 24 (1898) 1 e39.

[36] Y.S. Ho, G. McKay, Pseudo-second order model for sorption processes, Process Biochem. 34 (5) (1999) $451 \mathrm{e} 465$.

[37] I. Langmuir, The adsorption of gases on plane surfaces of glass, mica and platinum, J. Am. Chem. Soc. 40 (9) (1918) $1361 \mathrm{e} 1403$.

[38] H.M.F. Freundlich, Über die adsorption in Ifasungen, Z. fur Phys. Chem. 57 (1906) 385e470.

[39] H. Zollinger, in: Color Chemistry: Syntheses, Properties, and Applications of Organic Dyes and Pigments, Wiley, 2003.

[40] S.R. Valandro, A.L. Poli, M.G. Neumann, C.C. Schmitt, Photophysics of Aur- amine O adsorbed on solid clays, J. Luminescence 161 (2015) 209 e213.

[41] M. Samuels, O. Mor, G. Rytwo, Metachromasy as an indicator of photo- stabilization of methylene blue adsorbed to clays and minerals, J. Photochem. Photobiol. B Biol. 121 (2013) $23 e 26$.

[42] C. Dobrogowska, L.G. Hepler, D.K. Ghosh, S. Yariv, Metachromasy in clay mineral systems spectrophotometric and calorimetric study of the adsorp- tion of crystal-violet and ethyl violet by Na-montmorillonit and by Na- kaolinite, J. Therm. Anal. 37 (6) (1991) 1347e1356.

[43] M. Bouraada, M. Lafjah, M.S. Ouali, L.C. de Menorval, Basic dye removal from aqueous solutions by dodecylsulfate- and dodecyl benzene sulfonate- intercalated hydrotalcite, J. Hazard. Mater. 153 (3) (2008) 911e918.

[44] Y. Guo, H. Zhang, L. Zhao, G.-D. Li, J.-S. Chen, L. Xu, Synthesis and character- ization of CdeCr and ZneCdeCr layered double hydroxides intercalated with dodecyl sulfate, J. Solid State Chem. 178 (6) (2005) 1830e1836.

[45] J.T. Kloprogge, R.L. Frost, in: V. Rives (Ed.), Layered Double Hydroxides: Pre- sent and Furure, Nova Science Publishers, 2006, pp. $153 e 215$. 
[46] J.T. Kloprogge, L. Hickey, R.L. Frost, FT-Raman and FT-IR spectroscopic study of synthetic Mg/Zn/AIhydrotalcites, J. Raman Spectrosc. 35 (2004).

[47] F.R. Costa, A. Leuteritz, U. Wagenknecht, D. Jehnichen, L. H€ußler, G. Heinrich, Intercalation of MgeAl layered double hydroxide by anionic surfactants: preparation and characterization, Appl. Clay Sci. 38 (3e4) (2008) $153 e 164$.

[48] S. Xu, M.-C. Liao, H.-Y. Zeng, X.-J. Liu, J.-Z. Du, P.-X. Ding, W. Zhang, Surface modification and dissolution behavior of MgeAl hydrotalcite particles,

J. Taiwan Inst. Chem. Eng. 56 (2015) 174e180.

[49] V.A. Drits, A.S. Booking, in: V. Rives (Ed.), Layered Double Hydroxides: Present and Future, Nova Science Publishers, 2006.

[50] G. Besson, V.A. Drits, Refined relationships between chemical composition of dioctahedral fine-grained mica minerals and their infrared spectra within the oh stretching region. Part I: identification of the oh stretching bands, Clay Clay Miner. 45 (2) (1997) 158e169.

[51] J. Pérez-Ramírez, S. Abelló, N.M. Van Der Pers, Influence of the divalent cation on the thermal activation and reconstruction of hydrotalcite-like compounds, J. Phys. Chem.

C 111 (9) (2007) 3642e3650.

[52] F. Cavani, F. Trifirò, A. Vaccari, Hydrotalcite-type anionic clays: preparation, properties and applications, Catal. Today 11 (2) (1991) $173 e 301$.

[53] M. Sánchez-Cantú, J.A. Galicia-Aguilar, D. Santamaría-Juárez, L.E. Hernández- Moreno, Evaluation of the mixed oxides produced from hydrotalcite-like compound's thermal treatment in arsenic uptake, Appl. Clay Sci. 121 e122 (2016) $146 e 153$.

${ }_{[54]}$ L. Schreyeck, A. Wlosik, H. Fuzellier, Influence of the synthesis route on MgAl2O4 spinel properties, J. Mater. Chem. 11 (2) (2001) 483e486.

[55] M. Thommes, K. Kaneko, A.V. Neimark, P. Olivier, F. Rodriguez-Reinoso,

J. Rouquerol, K.S.W. Sing, Physisorption of gases, with special reference to the evaluation of surface area and pore size distribution (IUPAC Technical Report), Pure Appl. Chem. 87 (9e10) (2015) $1051 \mathrm{e} 1069$.

[56] M.A. Ulibarri, M.C. Hermosin, in: V. Rives (Ed.), Layered Double Hyeroxides: Present and Future, Nova Science Publishers, New York, 2006.

[57] P.W. Schindler, W. Stumm, in: W. Stumm (Ed.), Aquatic Surface Chamistry, Wiley, New York, 1987.

[58] P.W. Schindler, G. Sposito, in: G.H. Bolt, M.F. De Boodt, M.H.B. Hayes, M.B. McBride (Eds.), Interactions at the Soil Colloid - Soil Solution Interface, Springer-Science Business MEdai, B.V, 1991.

[59] M. Thommes, Physical adsorption characterization of nanoporous materials, Chem. Ing. Tech. 82 (7) (2010) 1059e1073. 
[6o] D.G. Evans, R.C.T. Slade, in: X. Duan, D.G. Evans (Eds.), Layered Double Hy- droxides, Springer, 2005

[61] WHO/SDE/PHE/OEH/06.02 WHO Air Quality Guidelines for Particulate Matter, Ozone, Nitrogen Dioxide and Sulfur Dioxide. Global Update 2005, World Health Organization.

[62] J.G. Ayres, in: R.E. Hester, R.M. Harrison (Eds.), Air Pollution and Health, Royal Society of Chemistry, Cambridge, 1998.

[63] M. Winterdahl, K. Bishop, M. Erlandsson, in: B. Freedman (Ed.), Global Envi- ronmnet Change, Springer, 2014.

[64] W.T. Reichle, S.Y. Kang, D.S. Everhardt, The nature of the thermal decomposition of a catalytically active anionic clay mineral, J. Catal. 101 (2) (1986) 352 e359.

${ }_{\left[{ }_{65}\right]}$ P. Ku'strowski, L. Chmielarz, E. Bozek, M. Sawalha, F. Roessner, Acidity and basicity of hydrotalcite derived mixed MgeAl oxides studied by test reaction of $\mathrm{MBOH}$ conversion and temperature programmed desorption of NH3 and CO2, Mater. Res. Bull. 39 (2) (2004) $263 e 281$.

[66] V.R.L. Constantino, T.J. Pinnavdia, Basic properties of Mg2 1-xAl3 x layered double hydroxides intercalated by carbonate, hydroxide, chloride, and sulfate anions, Inorg. Chem. 34 (4) (1995) $883 e 892$.

[67] R. Aringhieri, G. Pardini, M. Gispert, A. Sole, Testing a simple methylene blue method for surface area estimation in soils, Agrochimica 36 (3) (1992) 224e232.

[68] E. Ruiz-Hitzky, P. Aranda, J.M. Saerratosa, in: S.M. Auerbach, K.A. Carrado, P.K. Dutta (Eds.), Handbook of Layered Materials, Marcal Dekker, New York, 2004.

[69] A. We grzyn, A. Rafalska-Łasocha, D. Majda, R. Dziembaj, H. Papp, The influ- ence of mixed anionic composition of MgeAl hydrotalcites on the thermal decomposition mechanism based on in situ study, J. Therm. Anal. Calorim. 99 (2) (2010) 443e457.

[7о] U. Costantino, N. Coletti, M. Nocchetti, G.G. Aloisi, F. Elisei, Anion exchange of Methyl orange into $\mathrm{Zn} \mathrm{Al} \mathrm{synthetic} \mathrm{hydrotalcite} \mathrm{and} \mathrm{photophysical} \mathrm{characterization} \mathrm{of} \mathrm{the} \mathrm{intercalates}$ obtained, Langmuir 15 (13) (1999) 4454e4460.

[71] G.C.C. Tang, Roles of Background Compound Molecular Size and Adsorbent Pore Size Distribution in Competitive Adsorption on Activated Carbon, Uni- versity of Illinois at UrbanaChampaign, 2007. 